\title{
Manajemen Pengelolaan Fasilitas Olahraga Milik Pemerintah Kabupaten Ngawi Tahun 2018
}

\author{
Lingga Purnama, Farid Helmi Setyawan \\ PENJASKESREK, STKIP Modern Ngawi \\ lingga721@gmail.com, faridhelmi@stkipmodernngawi.ac.id
}

\begin{abstract}
Abstrak
Tujuan penelitian ini adalah untuk mengetahui tentang: 1) Manajemen pengelolaan fasilitas olahraga GOR Bung Hatta Kabupaten Ngawi (GBH) yang terdiri dari Gedung Olahraga (GOR) lapangan basket dan lapangan tenis di Kabupaten Ngawi tahun 2018.

Penelitian ini tentang Manajemen pengelolaan fasilitas olahraga milik pemerintah Kabupaten Ngawi Tahun 2018, merupakan penelitian deskriptif yang bersifat pengembangan dengan menggunakan data kualitatif, penelitian deskriptif merupakan penelitian non hipotesis sehingga dalam langkah penelitiannya tidak perlu merumuskan hipotesis. Dengan Sasaran dalam penelitian ini adalah: 1) pelaksanaan manajemen pengelolaan fasilitas olahraga Stadion GOR Bung Hatta (GBH) yang terdiri dari Gedung Olahraga (GOR) lapangan basket dan lapangan tenis di Kabupaten Ngawi Tahun 2018. Sedangkan metode pengumpulan data yang digunakan dalam penelitian ini, yaitu: teknik observasi, wawancara sebagai alat pengumpul data, dan dokumentasi sebagai data pelengkap.

Hasil penelitian ini adalah: 1) Manajemen perencanaan pengelolaan fasilitas olahraga yang sangat baik telah diterapkan pada GOR Bung Hatta memiliki perencanaan cukup baik sedangkan Lapangan basket dan Lapangan Tenis kurang baik. 2) Manajemen pengorgasisasian pengelolaan fasilitas GOR Bung sudah sangat baik, Lapangan basket dan lapangan tenis cukup baik. 3) Manajemen pengawasan pengelolaan fasilitas yang telah dilakukan dengan baik adalah oleh pengelola di GOR Bung Hatta, lapangan futsal, Sedangkan lapangan tenis melakukan fungsi actuating yang cukup baik. 4) Manajemen penggerak pengelolaan fasilitas telah dilakukan dengan baik adalah oleh pengelola di GOR Bung Hatta. Sedangkan lapangan basket dan lapangan tenis melakukan fungsi pengawasan yang cukup baik. GOR Bung Hatta karena mulai sepi dan hanya digunakan untuk pemusatan latihan para atlit kurang baik dalam pengawasan oleh pihak pengelola.
\end{abstract}

Kata Kunci: Manajemen, pengelolaan, fasilitas

\section{PENDAHULUAN}

Kemajuan pembangunan olahraga berorientasi pada 3 koridor yaitu: 1) pembangunan olahraga pendidikan, 2) pembangunan olahraga prestasi, 3) pembangunan olahraga masyarakat/olahraga rekreasi, maka dengan demikian tujuan olahraga yang sebenarnya akan dapat tercapai secara efektif jika terpenuhinya sebuah standarisasi sarana-prasarana keolahragaan. Dalam Kamus Besar Bahasa Indonesia (2008;768) disebutkan: "sarana adalah segala sesuatu yang dipakai sebagai alat dalam mencapai makna dan tujuan.
Sedangkan prasarana adalah segala sesuatu yang merupakan penunjang utama terselenggaranya suatu proses. Sedangkan Sumaryanto $(2005 ; 13)$ "sarana adalah alat fisik untuk menyampaikan pembelajaran".

Sebagaimana telah dijelaskan dalam Peraturan Pemerintah (PP) No. 16 tahun 2007, pasal 84 dan 85 berkaitan tentang standarisasi nasional keolahragaan bertujuan untuk menjamin mutu penyelenggaraan sistem keolahragaan nasional dimana didalamnya terdapat ruang lingkup standar keolahragaan, yang meliputi: 1) Kompetensi tenaga 
keolahragaan, 2) Isi program penataran/pelatihan tenaga keolahragaan, 3) Sarana dan prasarana olahraga, 4. Pengelolaan organisasi keolahragaan, 5) Penyelenggaraan keolahragaan, dan 6) Pelayanan minimal keolahragaan. Namun setelah melihat realita yang terjadi dilapangan, ternyata di beberapa daerah implementasi PP No. 16 tahun 2007 tersebut ternyata belum sepadan dengan maksud serta tujuan yang hendak dicanangkan oleh pemerintah. Apabila melihat fenomena yang terjadi di daerah saat ini muncul sebuah trend dimana menjadikan olahraga hanya sebuah event (perlombaan/pertandingan) demi sebuah kepentingan tertentu dan terkesan ajang pesta pora yang menghabiskan banyak biaya.

Perkembangan teknologi yang semakin pesat membuat banyak orang malas untuk melaksanakan aktivitas gerak, banyak orang memiliki kecenderungan untuk memanfaatkan fasilitas yang sungguh praktis, pemerintah lebih memprioritaskan pembangunan gedung-gedung pencakar langit, pembangunan jalan (fly over) dan beberapa taman kota yang dibuat dan berfungsi hanya untuk jantung kota sekaligus menunjang keindahan kota. Masyarakat hanya disuguhkan tempat "nongkrong" dan mall yang berdampak pada kehidupan konsumtif masyarakat. Sebegitu minimnya ruang untuk dijadikan tempat berolahraga, di kota-kota besar bisa dilihat dan dirasakan akan perlunya tempattempat untuk berolahraga. Disemua tempat terbuka, taman-taman, jalan-jalan baik jalan mobil maupun jalur kereta api dijadikan tempattempat berolahraga, terutama oleh anak-anak generasi muda yang diharapkan tumbuh menjadi tunas bangsa. Mereka bermain, berolahraga tidak lagi menghiraukan larangan penjaga taman, bahkan bahaya yang mengancam tidak dihiraukan. Mereka bergerak dan berolahraga karena secara alamiah membutuhkannya demi untuk perkembanagan jasmani dan rohaninya. Jadi penyediaan fasilitas terbuka merupakan dasar, kebutuhan pokok dari perencanaan olahraga.

Hasil observasi penulis di kabupten Ngawi, yaitu penulis menemukan fenomena, yaitu: 1) Masyarakat kabupaten Ngawi sangat gemar melakukan olahraga baik di dalam ruangan (indoor) maupuan di luar lapangan (outdoor). 2) Kabupaten Ngawi mempunyai beberapa prasarana olahraga dengan fasilitas olahraga yang cukup memadai untuk mendukung kegiatan olahraga masyarakat di kabupaten Ngawi, salah satunya yaitu GOR Bung Hatta Ngawi merupakan suatu sentral gedung olahraga di kabupaten Ngawi. Di dalamnya terdapat satu lapangan dan bisa digunakan untuk olahraga basket dan volly. Gedung ini bersifat multifungsi yaitu dapat dipakai untuk berolahraga dan disewakan untuk acara umum seperti, pernikahan, pertunjukan musik, dan masih banyak lagi. Konsepsi awal dari pembangunan gelanggang olahraga ini diharapkan menjadi kawasan olahraga terpadu, yang terdiri dari lapangan basket, volley dan tennis, tetapi seiring dengan kurangnya asupan dana dari pihak investor maka gelanggang ini yang diutamakan adalah lapangan basket dan vollynya. Selain dari GOR Bung Hatta tersebut masih banyak fasilitas olahraga lainnya diantaranya: stadion, lapangan futsal outdoor dan lapangan tenis.

Seiring dengan kemajuan perekonomian di kabupaten Ngawi, manajemen pengelolaan fasilitas olahraga yang tidak tepat dapat mempengaruhi pembangunan infrastruktur pemerintahan kabupaten Ngawi khususnya dalam bidang olahraga. Keseriusan dalam mengelola fungsi manajemen harus memiliki standar nasional maupun internasional sehingga kebutuhan olahraga bagi masyarakat kabupaten Ngawi dapat terpenuhi dengan baik. Fungsi manajemen adalah elemen-elemen dasar yang akan selalu ada dan melekat didalam proses manajemen yang akan dijadikan acuan oleh manajer dalam melaksanakan kegiatan untuk 
mencapai tujuan. Ada empat fungsi fundamental dari manajemen, biasanya dikenal dengan singkatan "POAC" yaitu: perencanaan (planning), perorganisasian (organizing), pengarahan (directing), kepemimpinan (leading), dan pengawasan (controlling) (Mugiyo Hartono, 2010; 10).

Melihat dari latar belakang masalah diatas, maka penulis sangat tertarik dan berminat untuk meneliti tentang bagaimana "Manajemen Pengelolaan Fasilitas Olahraga Milik Pemerintah Kabupaten Ngawi Tahun 2018".

Berdasarkan latar belakang yang telah diuraikan diatas maka dapat dirumuskan permasalahannya adalah: Bagaimanakah manajemen pengelolaan fasilitas olahraga GOR Bung Hatta di kabupaten Ngawi tahun 2018.

Adapun tujuan dari penelitian adalah untuk mengetahui: Manajemen pengelolaan fasilitas olahraga GOR Bung Hatta yang terdiri dari lapangan basket, volly dan lapangan tenis di kabupaten Ngawi tahun 2018.

Dalam penelitiaan ini dirumuskan beberapa kegunaan, antara lain sebagai berikut:

1. Manfaat Teoritis

a. Menambah ilmu pengetahuan tentang manajemen pengelolaan fasilitas olahraga milik pemerintah kabupaten Ngawi tahun 2018.

b. Memperluas pemahaman mengenai manajemen pengelolaan fasilitas olahraga milik pemerintah kabupaten Ngawi tahun 2018.

c. Penelitian ini dapat dijadikan sebagai bahan refrensi atau bacaan khususnya tentang manajemen pengelolaan fasilitas olahraga.

2. Manfaat Praktis

a. Sebagai gambaran oleh pemerintah kabupaten lain untuk dijadikan refrensi dalam melakukan pengadaan fasilitas olahraga dan mutu menejemen yang lebih baik. b. Dapat mengetahui nilai kepuasan bagi masyarakat pengguna akan penyediaan fasilitas olahraga yang sudah disediakan oleh pemerintah kabupaten Ngawi.

c. Bagi peneliti dapat meningkatkan pengetahuan dan wawasan mengenai manajemen pengelolaan fasilitas olahraga.

\section{Definisi Istilah}

1. Manajemen

Di buku Erni Trisnawati Sule dan Kurniawan Saefullah kata "manajemenecee tampaknya sudah begitu sering kita dengar. Manajemen erat kaitannya dengan konsep organisasi. Sehubungan dengan hal tersebut, maka ada baiknya kita memahami dulu pengertian organisasi. Menurut Griffin (2002), organisasi adalah a group of people working together in a structured and coordinated fashion to achieve a set of goals/Organisasi adalah sekelompok orang yang bekerja sama dalam struktur dan koordinasi tertentu dalam mencapai serangkaian tujuan tertentu. Atau dengan bahasa lain, penulis mendefinisikan organisasi sebagai sekumpulan orang atau kelompok yang memiliki tujuan tertentu dan berupaya untuk mewujudkan tujuannya tersebut melalui kerjasama. Manajemen secara pengertian, sebagaimana dikemukakan oleh Mary Parker Follet (1997), adalah seni dalam menyelesaikan sesuatu melalui orang lain. Management is the art of getting things done through people.

\section{Pengelolaan}

Menurut Harsono $(1977 ; 121)$ pengelolaan adalah suatu istilah yang berasal dari kata "kelolae mengandung arti serangkaian usaha yang bertujuan untuk menggali dan memanfaatkan segala potensi yang dimiliki secara efektif dan efisien guna mencapai tujuan tertentu yang telah direncanakan sebelumnya.

Dari uraian diatas dapatlah disimpulkan bahwa yang dimaksud dengan pengelolaan adalah suatu rangkaian kegiatan yang bertujuan 
menggali dan memanfaatkan sumber daya alam yang dimiliki secara efektif untuk mencapai tujuan organisasi yang telah ditentukan.

3. Manajemen Pengelolaan

Pendapat peneliti mengenai manajemen pengelolaan yaitu merupakan suatu proses yang di dalamnya terdapat kerjasama melalui orangorang maupun sumber daya organisasi untuk menyesuaikan strategi pengelolaan supaya mereka dapat mengatasi perubahan dalam interaksi atas manusia untuk mencapai tujuan.

4. Sarana Prasarana

Menurut Kamus Besar Bahasa Indonesia (2001; 999) dijelaskan, sarana adalah segala sesuatu yang dipakai sebagai alat dalam mencapai maksud dan tujuan. Contoh : bola, raket, pemukul, tongkat, balok, raket tenis meja, shuttle cock, dll. Sarana atau alat sangat penting dalam memberikan motivasi peserta didik dengan sungguh-sungguh dan akhirnya tujuan aktivitas dapat tercapai. Menurut Ratal Wirjasantoso $(1984 ; 157)$ alat-alat olahraga biasanya dipakai dalam waktu relatif pendek misalnya : bola, raket, jaring, pemukul bola kasti, dan sebagainya. Alat-alat olahraga biasanya tidak dapat bertahan dalam waktu lama, alat akan sering rusak bila sering dipakai dalam kegiatan pembelajaran pendidikan jasmani, agar alat dapat bertahan lama harus dirawat dengan baik.

Prasarana adalah segala sesuatu yang merupakan penunjang utama terselenggaranya suatu proses (Kamus Besar Bahasa Indonesia). Sarana prasarana adalah alat secara fisik untuk menyampaikan isi pembelajaran (Sagne dan Brigs dalam Latuheru, 1998; 13). Dari berbagai definisi menurut para ahli dapat diartikan bahwa sarana prasarana adalah sumber daya pendukung yang terdiri dari segala bentuk jenis bangunan/tanpa bangunan beserta dengan perlengkapannya dan memenuhi persyaratan untuk pelaksanaan kegiatan.

\section{METODE}

Lokasi yang dipilih pada penelitian ini meliputi Gedung Olahraga (GOR) Bung Hatta yang meliputi lapangan basket, volley dan tenis. Sasaran dalam penelitian ini adalah: 1) pelaksanaan manajemen pengelolaan fasilitas olahraga dari Gedung Olahraga (GOR) Bung Hatta lapangan basket, volly dan lapangan tenis di kabupaten Ngawi Tahun 2018.

Subyek penelitian merupakan sumber data yang akan digali oleh peneliti kepada pihak-pihak yang dijadikan sebagai sampel yang berupa manusia/responden. Informasi yang akan dicari tidak hanya berupa verbal tetapi berupa tindakan dan aktivitas subyek penelitian juga. Subyek penelitian ini adalah manajemen pengelolaan fasilitas olahraga diantaranya: Gedung Olahraga (GOR) lapangan basket, volly dan lapangan tenis, lapangan kabupaten Ngawi.

Pada dasarnya bagian ini menjelaskan bagaimana penelitian itu dilakukan. Materi pokok bagian ini adalah: (1) rancangan penelitian; (2) populasi dan sampel (sasaran penelitian); (3) teknik pengumpulan data dan pengembangan instrumen; (4) dan teknik analisis data. Untuk penelitian yang menggunakan alat dan bahan, perlu dituliskan spesifikasi alat dan bahannya. Spesifikasi alat menggambarkan kecanggihan alat yang digunakan sedangkan spesifikasi bahan menggambarkan macam bahan yang digunakan.

Untuk penelitian kualitatif seperti penelitian tindakan kelas, etnografi, fenomenologi, studi kasus, dan lain-lain, perlu ditambahkan kehadiran peneliti, subyek penelitian, informan yang ikut membantu beserta cara-cara menggali data-data penelitian, lokasi dan lama penelitian serta uraian mengenai pengecekan keabsahan hasil penelitian.

Penelitian tentang Manajemen pengelolaan fasilitas olahraga milik pemerintah Kabupaten Ngawi Tahun 2018 adalah penelitian deskriptif yang bersifat pengembangan dengan 
menggunakan data kualitatif, penelitian deskriptif merupakan penelitian non hipotesis sehingga dalam langkah penelitiannya tidak perlu merumuskan hipotesis.

Data yang dikumpulkan berupa kata-kata, gambar, dan bukan angka-angka. Data tersebut berasal dari naskah wawacara, catatan-lapangan, foto, dokumen pribadi, catatan atau memo dan dokumen-dokumen resmi.

Sesuai dengan tujuan dan perumusan masalah penelitian, maka data yang diperlukan untuk mengetahui gambaran pelaksanaan manajemen pengelolaan fasilitas olahraga milik pemerintah kabupaten Ngawi Tahun 2018 adalah:

a. Data mengenai sistem manajemen pengelolaan fasilitas olahraga milik pemerintah kabupaten Ngawi Tahun 2018.

b. Data mengenai pelaksanaan manajemen pengelolaan fasilitas olahraga milik pemerintah kabupaten Ngawi Tahun 2018.

Sumber data dalam penelitian adalah subjek dari mana data dapat diperoleh. Sumber data merupakan segala keterangan atau informasi berkaitan mengenai hal dengan masalah yang dibahas. Adapun sumber data yang digunakan adalah seperti di bawah ini:

a. Sumber data primer yaitu sumber data yang mempunyai kaitan langsung dengan masalah-masalah yang dibahas, data ini diperoleh dari wawancara mendalam dan observasi.

b. Sumber data sekunder yaitu sumber data yang digunakan atau diperoleh secara tidak langsung dalam permasalahan yang dibahas. Data ini diperoleh dari buku laporan, dokumen-dokumen, brosur, monografi, dan buku-bukuliteratur.

Berikut ini akan diuraikan beberapa metode pengumpulan data yang digunakan dalam penelitian ini, yaitu: Wawancara, Observasi, Dokumentasi
Berkaitan dengan analisis data, adapun teknik analisis yang digunakan dalam penelitian ini adalah:

1. Teknik Analisis Kualitatif

Analisis secara kualitatif digunakan untuk menganalisis data yang diperoleh dari wawancara dan dokumentasi. Tahap-tahap yang dilakukan dalam analisis kualitatif adalah sebagai berikut:

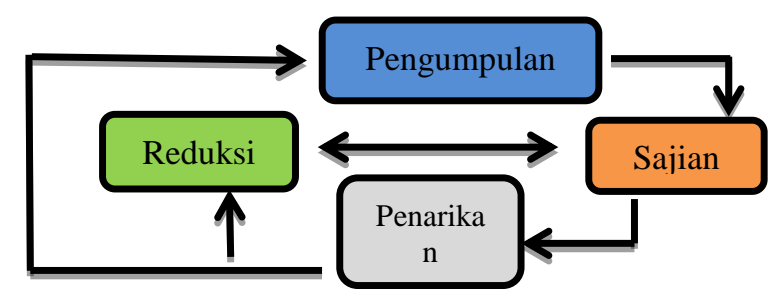

Gambar 1 Analisis Data Interaktif

(Interactive Model of Analysis)

a. Reduksi Data.

b. Penyajian data

c. Penarikan Kesimpulan/verifikasi

d. Validitasi Data

Dalam hal ini jangan banyak mengharapkan bahwa hasil pembandingan tersebut merupakan kesamaan pandangan, pendapat, ataupun pemikiran yang terpenting disini ialah bias mengetahui adanya alasanalasan terjadinya perbedaan tersebut.

\section{HASIL DAN PEMBAHASAN}

1. Manajemen Pengelolaan Fasilitas Olahraga Milik Pemerintah Kabupaten Ngawi

Penelitian tentang manajemen pengelolaan fasilitas olahraga milik pemerintah Kabupaten Ngawi ini dilakukan pada satu fasilitas olahraga yaitu GOR Bung Hatta Ngawi. Pengelolaan fasilitas olahraga mencakup fungsi-fungsi manajemen yaitu mencakup fungsi perencanaan (Planning), fungsi pengorganisasian (Organizing), fungsi pengawasan (Controlling) dan fungsi penggerak (Actuating).

2. GOR Bung Hatta Ngawi

Gedung Olahraga Bung Hatta merupakan gedung serbaguna yang dimiliki pemerintah Kabupaten Ngawi, gedung ini 
memiliki kapasitas sekitar 1000 pengunjung dan gedung ini merupakan gedung olahraga yaitu gedung lapangan basket berstandart nasional, di dalam gedung terdapat satu lapangan basket tetapi juga bisa digunakan untuk cabang olahraga voli.

Gedung Olahraga Bung Hatta merupakan gedung multifungsi, gedung ini merupakan bersifat umum dan bisa di sewa oleh khalayak umum, biasanya gedung ini digunakan sebagai acara pertunjukan musik, pernikahan, dan event olahraga, gedung ini terletak dibagian kota ngawi bagian selatan, tepatnya jalan Dadapan Klitik Geneng atau juga biasa disebut terminal lama.

Gedung Olahraga Bung Hatta terdiri dari (1) satu lapangan basket, (2) dua lapangan voli, (3) satu lapangan tenis, (4) Tribun penonton berkapasitas sekitar 1000 penonton, (5) Toilet dan (6) mushola. Protap pemakaian yaitu:

a. Petugas penjaga

1) Minimal 1 hari sekali memperiksa kondisi gedung.

2) Mempersiapkan kebutuhan konsumen apabila ada sebuah event.

3) Mengkoordinasi seluruh tenaga setiap akan ada pemakaiaan.

4) Melakukan evaluasi setelah ada pemakaian.

5) Membersihan dan merawat setelah ada pemakaian.

b. Pemakai

1) Pemakai tidak boleh memakai tanpa seijin pengelola.

2) Menjaga keamanan, kenyamanan, kebersihan.

3) Dilarang berbuat kerusuhan.

4) Pengunjung harus mematuhi peraturan yang ada.

Manajemen pengelolaan fasilitas di Gedung Olahraga Bung Hatta dalam hal perencanaan seperti yang diungkapkan oleh pengelola dalam wawancara yaitu sudah baik karena setiap periode pasti ada rencana pembenahan. Kendala dalam pengelolaan fasilitas ini adalah minimnya anggaran APBD untuk perawatan gedung oleh karena itu pengelola memanfaatkan masyarakat umum yang ingin memakai gedung dengan membayar uang kebersihan atau uang sewa sesuai Perda Kabupaten Ngawi bahwa untuk penggunaan gedung serba guna dikenakan biaya Rp. 1.700 .000 jika pagi hari dan Rp. 2.300.000 pada malam hari (event besar), dan biaya sewa untuk latihan basket atau voli Rp. 30.000 jika siang hari dan Rp. 40.000 pada malam hari. Sistem penggunaan dana merupakan dana yang berasal dari APBD dan biaya sewa gedung dari masyarakat umum yang menggunakan gedung serba guna sehingga dapat digunakan untuk merawat gedung tersebut. Sistem pengawasan gedung dilakukan dengan cara pengecekan kondisi gedung sebelum dan setelah digunakan. Selain itu, kegiatan perawatan atau pembersihan dilakukan tiap hari oleh petugas kebersihan. Pengelolaan yang baik dapat dilihat dari kondisi gedung serba guna yang tergolong megah dan banyak diminati oleh masyarakat untuk digunakan berbagai acara tertentu.

Untuk lebih jelasnya hasil peneltian melalui wawancara dan observasi di Gedung Olahraga Bung Hatta dapat dirangkum dalam tabel di bawah ini:

1. Perencanaan (Planning)

Fungsi manajemen yang pertama sebagai penentu arah pembangunan manajemen pengelolaan fasilitas olahraga di kabupaten Jepara adalah perencanaan. Perencanaan adalah sebuah dasar dari pelaksanaan yang akan dikerjakan dalam suatu organisasi atau perusahaan. Perencanaan yang baik akan memudahkan proses berlangsungnya tahapan-tahapan selanjutnya. GOR Bung Hatta Ngawi 
mempunyai perencanaan yang matang dan sangat baik untuk menjadi stadion nasional yang digunakan sebagai central olahraga dan digunakan untuk pertandinganpertandingan tingkat daerah maupun nasional. Pengelola stadion membuat perencanaan yang sistematis tiap awal tahun dengan menambah atau pembangunan beberapa fasilitas pendukung. Perencanaan fasilitas di GOR Bung Hatta Ngawi Kartini bisa dikatakan cukup baik. Terbukti dengan tidak adanya keluhan tentang hal-hal yang berhubungan dengan gor tersebut dan pengguna merasa cukup puas dengan kelengkapan sarana dan parasarana dalam gor yang telah sesuai dengan standar nasional. Selain itu, pengelola juga telah memberikan pelayanan yang ramah. Sistem perencanaan yang digunakan dalam melengkapi/menambah sarana dan fasilitas pendukung gor dengan cara mengelola anggaran APBD dan uang sewa dari penggunaan stadion tersebut.

Pengelola Lapangan tenis telah melakukan perencanaan pengembangan fasilitas namun masih kurang baik. Salah satu fasilitas yang belum terpenuhi ialah toilet dan net, sehingga sering mendapat komplein dari pengguna lapangan tenis. Sistem penggunaan dana merupakan dana yang berasal dari APBD dan iuran kebersihan dari masyarakat umum yang menggunakan lapangan tenis tersebut masih belum mencukupi untuk perbaikan dan penambahan fasilitas di dalam lapangan tenis tersebut. Perencanaan yang kurang baik juga dapat dilihat dari tidak adanya lampu penerangan sehingga tidak dapat digunakan pada malam hari.

2. Pengorganisasian (Organizing)

Pengorganisasian adalah penentuan sumber daya dan kegiatan- kegiatan yang dibutuhkan untuk mencapai tujuan organisasi, perancangan dan pengembangan suatu organisasi atau kelompok kerja yang akan dapat membawa hal-hal tersebut kearah tujuan, penugasan tanggung jawab tertentu dan kemudian, pendelegasian wewenang yang diperlukan kepada individuindividu untuk melaksanakan tugastugasnya. Fungsi ini menciptakan struktur formal dimana pekerjaan ditetapkan, dibagi, dan dikoordinasikan.

Berdasarkan hasil pengamatan di lapangan, fungsi pengorganisasian GOR Bung Hatta Ngawi berjalan dengan baik, hal ini dapat kita lihat dari adanya koordinasi dengan karyawan atau petugas kebersihan di stadion tersebut. Semua memiliki jod diskripsi masing-masing. Pengelola memberikan tugas dan tanggungjawab untuk menjaga kebersihan dan keamanan di lingkungan gor terutama ketika digunakan latihan. Para petugas kebersihan selalu membersihkan gor tiap pagi dan sore. Pengorganisasian lain yang dilakukan yaitu terhadap jadwal latihan, masyarakat umum diijinkan menggunakan lapangan atau gor ketika tidak berbenturan dengan kegiatan yang sudah ditentukan tanggalnya dahulu.

Lapangan tenis ini dibangun bersebelahan dengan gedung gor dengan bertujuan untuk memajukan olahraga tenis lapangan di Kabupaten Ngawi dan untuk pembibitan atlet muda. Pengorganisasi di lapangan tenis ini termasuk dalam kategori cukup baik. Pengelola telah menerapkan pengorganisasian yang cukup baik dilihat dari tertibnya perawatan gedung oleh para petugas sebelum dan sesudah pemakain lapangan tenis. Selain itu, pengelola juga rutin melakukan pelaporan penggunaan dana APBD dan dana sewa serta pengeluaran-pengeluaran tiap bulan dalam bentuk SPJ.

3. Penggerak (Actuating)

Fungsi pengarahan (Actuating) secara sederhana adalah untuk membuat para 
karyawan melakukan apa yang harus mereka lakukan. Fungsi ini melibatkan kualitas, gaya, dan kekuasaan pemimpin serta kegiatan-kegiatan kepemimpinan seperti komunikasi, motivasi dan disiplin. Fungsi actuating (penggerak) yang telah dilakukan dengan baik adalah oleh pengelola di GOR Bung Hatta Ngawi, lapangan tenis.. Untuk meningkatkan kualitas fasilitas dan pelayanan di GOR Bung Hatta Ngawi dan Lapangan Tenis, usaha yang dilakukan adalah selalu mengontrol sarana dan prasarana yang ada, sehingga apabila terjadi kerusakan bisa langsung diperbaiki.

Fungsi pelaksanaan/penggerakan (actuating) dalam manajemen pengelolaan fasilitas olahraga milik pemerintah Kabupaten Ngawi dilakukan untuk menggerakkan pengelola dan para karyawan/petugas kebersihan dalam menjalankan fasilitas olahraga tersebut agar sesuai dengan rencana maka diperlukan adanya tindakan untuk mengarahkan, membimbing, komunikasi dan motivasi. Ketua pengelola fasilitas olahraga telah memberikan arahan kepada pengelola bawahan dan petugas kebersihan untuk dapat melaksankan tugas dan tanggung jawab masing-masing. Setelah pengelola mendapatkan pengarahan dari ketua atau pimpinan maka selanjutnya menggerakkan para petugas kebersihan untuk menjaga kebersihan dan kenyamanan pengunjung atau pengguna fasilitas olahraga tersebut.

4. Pengawasan (Controlling)

Pengawasan (Controling) adalah penemuan dan penerapan cara dan peralatan untuk menjamin bahwa rencana telah dilaksanakan sesuai dengan yang telah ditetapkan. Fungsi pengawasan yang telah dilakukan dengan baik adalah oleh pengelola di GOR Bung Hatta Ngawi.
Sedangkan lapangan tenis melakukan fungsi pengawasan yang cukup baik.

Untuk menjamin terlaksananya tujuan masing-masing fasilitas olahraga di Kabupaten Ngawi, pengelola selalu melakukan kegiatan pengawasan. Dengan datang langsung ke lapangan dan melihat dari laporan pembukuan. Setiap bulan sekali pengelola memberikan laporan rutin mengenai kegiatan yang sudah berlangsung setiap harinya. Cara mengontrol para petugas kebersihan dengan cara meminta laporan rutin dan mengawasi langsung ke lapangan untuk melihat bagaiman kinerja para petugas kebersihan.

Fungsi pengawasan (controlling), dilakukan oleh pengelola fasilitas olahraga milik pemerintah Kabupaten Ngawi dilakukan dengan bertahap dan berjenjang mulai dari ketua/pimpinan pengurus sampai petugas kebersihan untuk mengawasi kegaiatan para pengguna fasilitas agar sesuai dengan Protap yang telah ditentukan. Pengawasan ini jadi dilakukan dengan melakukan pengecekan secara berkala terhadap fasilitas pendukung dan melakukan pemeliharaan tiap pagi dan sore.

Sistem pengawasan pada stadion GOR Bung Hatta Ngawi berjalan dengan efektif, pengawasan pelasanaan di setiap bidang dikontrol melalui format data yang harus di isi dalam setiap pelaksanaan tugas dalam masing - masing bidang. Hal ini dilakukan untuk mengetahui hal-hal yang masih kurang dan harus ditingkatkan untuk meningkatkan pelayanan kepada pelanggan.

\section{PENUTUP}

\section{Simpulan}

Berdasarkan hasil penelitian dan data yang diperoleh maka peneliti dapat menarik kesimpulan yaitu:

1. Manajemen perencanaan pengelolaan fasilitas olahraga yang baik telah diterapkan 
pada GOR Bung Hatta dan sedangkan Lapangan Tenis kurang baik. Akan tetapi perencanaan pengembangan GOR modern yang tidak hanya berfungsi sebagai sarana dan prasarana olahraga tetapi juga rekreasi dan bisnis. Peneliti menyimpulkan bahwa fokus perencanaan pengelola masih pada pembangunan dan perbaikan sarana dan prasarana yang ada pada GOR. Perencanaan pada tahap renovasi bangunan menjadi prioritas utama saat ini agar GOR dapat diguanakan untuk event lokal ataupun nasional sehingga pemasukan dan perputaran ekonomi masyarakat di kabupaten Ngawi dapat berkembang.

2. Manajemen pengorgasisasian pengelolaan fasilitas GOR Bung Hatta sudah baik, Lapangan tenis kurang baik.

3. Manajemen pengawasan pengelolaan fasilitas yang telah dilakukan dengan baik adalah oleh pengelola di GOR Bung Hatta dan lapangan tenis.

4. Manajemen penggerak pengelolaan fasilitas telah dilakukan dengan baik adalah oleh pengelola GOR Bung Hatta. Sedangkan lapangan tenis melakukan fungsi pengawasan yang kurang baik.

\section{DAFTAR PUSTAKA}

Collins Gem, (1997). Kamus Suku Matematika. Jakarta: Erlangga.

Departemen Pendidikan dan Kebudayaan."KamusBesar Bahasa Indonesia”. Ed Keempat. Jakarta: PT GramediaPustakaUtama, 2008.

Dunn, William N. (2003). Analisis Kebijakan Publik. Yogyakarta : Gadjah Mada University Press.

George. R. Terry. (2003). PrinsipprinsipManajemen. Jakarta :Bumi Aksara

Harsuki. (2003). Pengantar Manajemen Olahraga. Jakarta :Rajawali Pers

Kristiyanto, Agus (2012) "Penelitian Tindakan kelas " Surakarta Sebelas Maret Universiti.
Maksum. (2004). Madrasah Sejarah dan Perkembangannya. Bandung: Grafindo persada.

Mugiyo Hartono. (2010). Manajemen Keolahragaan. FIK UNNES.

Ratal, Wirjasantosa. (1984). Supervisi Pendidikan Olahraga. Jakarta: UNIVERSITAS INDONESIA.

Sentanoe K. (1983). Prinsip dan Teknik Manajemen. Yogyakarta : Ananda

Sumaryanto, et al. (2005). Analisis Kebijaksanaan Konversi Lahan Sawah ke Penggunaan Non Pertanian. Laporan Penelitian Tahun II. Pusat Penelitian Sosial Ekonomi Pertanian-Badan Penelitian dan Pengembangan Pertanian. (Tidak dipublikasikan).

Soepartono. (2000). Media Pembelajran. Jakarta: Depdiknas.

Sondang. P. Siagian. (1988). Fungsi-fungsi Manajemen. Jakarta :BumiAksara

Surachmad, Winarno. (1994). Pengantar Penelitian Ilmiah dan Dasar Metode Teknik, Transito, Bandung.

Strauss, Ansemdan Juliet Corbin. (1997). Dasar-Dasar Penelitian Kualitatif: Tata Langkah dan Teknik-teknik Teorisasi Data, Yogyakarta: Pustaka Pelajar.

Tomoliyus. (2010). Paduan Kepelatihan Sekolah

Dasar. Makalah. Yogyakarta. FIK UNY. 